\title{
Necessity of tricuspid valve replacement in a case with iatrogenic rupture of anterior leaflet by pacemaker lead
}

\author{
A Gurbuz, O Gokalp, U Yetkin*, H Iner, I Yurekli \\ From 23rd World Congress of the World Society of Cardio-Thoracic Surgeons \\ Split, Croatia. 12-15 September 2013
}

\section{Background}

Although there are many complications after pacemaker implantation, iatrogenic perforation of the tricuspid valve followed by tricuspid regurgitation is extremely rare.

\section{Method}

Our case was a 64-year-old male. He was implanted a VDD pacemaker (PM) at another institution 15 months before his admission to our clinic. Four months after that implantation, the pocket for generator was changed due to infection of the initial pocket. He was suffering from ulceration of the skin covering the generator and exposed leads. Our Department of Cardiology removed the generator and the leads.

\section{Results}

Control transthoracic and transesophageal echocardiography revealed that proximal part of the silicon tube left from the ventricular lead was prolapsing from right ventricle into the right atrium. A mobile mass of $9 \times 3 \mathrm{~mm}$ was also observed on this part. In addition, a severe tricuspid regurgitation was detected due to coaptation defect with a pulmonary arterial pressure of $55-60 \mathrm{~mm}$ $\mathrm{Hg}$ and dilated right cardiac chambers. Extraction of the silicon tube from right atrium using inflow occlusion on beating heart $(\mathrm{IOBH})$ technique was planned. But, iatrogenic perforation of the anterior leaflet of the tricuspid valve was detected and cardiopulmonary bypass was established. Perforation of the anterior leaflet and neartotal detachment of tricuspid valve were detected and therefore tricuspid valve was resected. Replacement with porcine bioprosthetic valve was performed. Postoperative

\footnotetext{
* Correspondence: ufuk_yetkin@yahoo.fr

Izmir Katip Celebi University Ataturk Training and Research Hospital,

Department of Cardiovascular Surgery, Turkey
}

period was event-free and our patient is recently under outpatient follow-up.

\section{Conclusion}

Although lead extraction using IOBH technique is an exclusive therapy, conventional cardiopulmonary bypass should be established and valvular repair/replacement should be carried out in cases with coincidental diagnosis of major iatrogenic valvular complication as in our case.

Published: 11 September 2013

doi:10.1186/1749-8090-8-S1-P23

Cite this article as: Gurbuz et al:: Necessity of tricuspid valve

replacement in a case with iatrogenic rupture of anterior leaflet by pacemaker lead. Journal of Cardiothoracic Surgery 2013 8(Suppl 1):P23.

Submit your next manuscript to BioMed Central and take full advantage of:

- Convenient online submission

- Thorough peer review

- No space constraints or color figure charges

- Immediate publication on acceptance

- Inclusion in PubMed, CAS, Scopus and Google Scholar

- Research which is freely available for redistribution

Submit your manuscript at www.biomedcentral.com/submit
() Biomed Central (c) 2013 Gurbuz et al; licensee BioMed Central Ltd. This is an Open Access article distributed under the terms of the Creative Commons Attribution License (http://creativecommons.org/licenses/by/2.0), which permits unrestricted use, distribution, and reproduction in any medium, provided the original work is properly cited. 